\title{
Exploring Terror Victims' Expectations of Government Communication
}

\author{
Daniel Robert Aswani ${ }^{*}$, Dr. Paul Mbutu ${ }^{2}$, Dr. Kinya Mwithia ${ }^{3}$ \\ ${ }^{1}$ Doctoral candidate Department of Strategic and organizational communication Daystar University \\ ${ }^{2}$ Senior Lecturer, Strategic and organizational communication Daystar University \\ ${ }^{3}$ Senior Lecturer and Head of Department, Strategic and organizational communication Daystar University \\ *Corresponding Author: Daniel Robert Aswani, Strategic and organizational communication department, \\ Daystar University.
}

\begin{abstract}
At the time of a terror attack, victims yearn for messages from the government so that they can make decisions on their safety and security. When the government communicates, the victims form perceptions towards such communication. The perceptions that victims of terror hold are partly attributed to the expectations that the victims have of government communication. This study explored terror victims' expectations of government communication. The study adopted a qualitative methodology and used hermeneutic phenomenological design. The findings showed that victims of terror have expectations of government communication ranging from the desire for personalized communication; agility in communication; transparent and prompt communication; well-coordinated messaging; and communicate power and authority. Different studies, both conceptual and speculative, point to the same expectations of the different audiences that consume government communication.
\end{abstract}

\section{INTRODUCTION}

A scene of a terror attack is often bloody - possibly with scores of injured people, lifeless bodies and a good number of first responders. Terrorists seek to destroy property and kill citizens of a given state, yet governments exist to protect the very lives and property of citizens. This conundrum creates anxious moments among citizens which can reflected in the questions that citizens pose at the time of an attack. The questions include: where was government when it all happened? Why did the government not forewarn citizens of the impending danger? Why are citizens exposed to terror attacks? What is the government saying about the attack? These questions are indicative of the citizen's heightened quest for communication from government during attacks. Since citizens are the audiences of government communication, the questions posed by citizens during a terror attack show a relationship between the government and the citizens where citizens form a better part of an audience on what the government communicates. Significantly, the questions reflects the expectations of citizens from their government. Citizens have some expectations of what the government needs to do, but more specifically on what the government needs to say. In many government systems, communication serves as a link between what the leaders and the led engage in. Government communication constitutes of "constant exchanges of information and communication about policies, ideas and decisions between the governed and the governed" (Canel \& Sanders, 2012: 85). Corporate communicators take a boundary spanning role where the publics are roped into the organization's agenda while at the same time allowing corporate communicators to relay feedback from the publics to the organization. Before, during and after a terror attack, citizens expect some communication from the government. Government communicators targets citizens as they explain policies, procedures and its efforts to ensure safety and security (Fairbanks, Plowman \& Rawlins, 2007). Specifically, in a democratic formation, the government is obligated to communicate to the citizens and answer the many questions that citizens have (Tench \& Yeomans, 2006, Young, 2007). Effective government communication happens when the informational needs of citizens are satiated. In this study, government was conceptualized as an organization which imbues government communicators to establish and maintain mutually beneficial relations between the organization and its publics (Argenti, 2013; Cornelissen, 2014). To do this, government communicators need to engage in stakeholder 
mapping where the organization's publics are segmented based on their needs, interests and concerns. Terrorism is conceptualized as violent communication - aimed at advancing political or social courses (Schmid, 2013). The effects of terrorism include murderous attacks (Rapin, 2011), injuries, wanton destruction of property, social and psychological trauma. Since acts of terror delimits the power of the state and refracts the social pact between the state and the citizens (Locke, 2014), it is imperative that the government communicates on terror. While it is assumed that at the time of an attack, government communication will focus on consoling and condoling with the victims, no concretized study has delved deeper to understand what citizens expectations of government communication. Kenya has had several attacks. The last major attack before the Garissa University attack was that on Westgate shopping mall. This attack led Kenyans to rally their thoughts shortly after the Westgate terror attack under the hashtag \# WeThe People- Questions on Westgate. This hashtag consolidated 84 questions that Kenyans wanted the government to answer. From the 84 questions, one notes the quest for information during times of an attack. Citizens seem interested in clarity especially on numbers of victims and attackers. There is need for government to communicate on terrorists' identities among other concerns. The questions also pointed out to the mixed voices that were heard when government spoke. With literature pointing to the possible quest for information among audiences, this study had an overarching objective of examining terror victims' perception towards government communication. Perceptions are partly built on the expectations that terror victims have of government communication. This paper addresses itself to the research question that sought to examine terror victims' expectations of government communication. This study was contextualized on the terror attack on 2 April 2015 at the Garissa University College. This was the second worse attack since the 1998 bombing of the USA embassy in Nairobi. Additionally, the attack was ranked top 20 worst attacks in the 2015 Global Terrorism Index (START, 2016) and the attack generated considerable government messages.

The study was theoretically framed within the constructs of the co-orientation theory advanced by McLeod and Chaffee (1973) and more recent times by Broom and Sha (2013). The theory helps examine the essences of perceived differences between what the organization communicates and what the audience receives and understands. In better understanding citizen expectations of government communication, the study reflected on the constructs of agreement, accuracy and congruency which were well grounded in the citizens' lived experiences. Lived experiences brought out the essences of the participants' text of life. Experiences were examined through phenomenological constructs (van Manen, 2016).

\section{Methodology}

This study was anchored in the constructivist paradigm where emphasis is placed on the individual's subjective experiences and how individual interpretations form part of the picture that people have of the external world. Truth is thus socially constructed as the intersubjective convergence of experiences depend on how people interact with one another. Careful that subjective thoughts require interrogation, we were interested in the "complexity of views rather than narrow the meanings into a few categories or ideas" Creswell (2013:24). We approached the study from a hermeneutic phenomenological design. Largely, phenomenological studies look at essences - that which makes something what it is (Moustakas, 1994, van Manen, 2016). The design has inklings from Edmund Husserl but builds on the shift argued in Martin Heidegger's hermeneutic phenomenology and as supported by other seminal figures such as Schleiermacher, Dilthey, Martin Heidegger, Hans-Georg Gadamer and Paul Ricoueur (De Gagne \& Walters, 2010; Gadamer, 2013; Crotty, 2015). This design enabled us secure rich description that related to with the phenomena under investigation. Using phenomenology helped us tap "the primordial contents of consciousness" (Crotty, 2015:96) as advanced in the Heideggerian hermeneutical circle.

\subsection{Data Collection}

Phenomenological studies focus on small samples which are then studied comprehensively (Miles \& Huberman, 1994). Previous sample projections had settled on 2-9 participants with increased projections settling on 1-30 participants (Colaizzi, 1978; Lincoln \& Guba, 1985; Parse, 1990; Dukes, 1984; Boyd, 2001; Smith, Flowers and Larkin, 2009; De Gagne and Waters, 2010; Straus \& Corbin, 1998: Shosha, 2010). Gentles, Charles, Ploeg and McKibbon (2015) argue a difference between sampling in hermeneutical and transcendental phenomenology. The authors propose 10 intense 
interviews for hermeneutical studies and 12 participants for transcendental phenomenology. In the end, sampling is a researcher's call and in this, the researcher is guided by time, resources and saturation (De Gagne \& Walters, 2010; Gill, 2014).

In this study, we conducted 10 in depth interviews and attained saturation after the eighth interview but went ahead to honor two more interviews. The 10 participants were sampled using snowballing sampling design and all the 10 met the set criteria. The interviews with each participant lasted between 45 and 60 minutes in the first interviews and between 20-30 minutes for multiple interviews. To triangulate the findings from interviews, we also used non-participant observation and document analysis methods. Document analysis generated secondary data from documents such as laws, policies, reports, circulars, speeches and pressers from government during the attack. To analyze documents, we skimmed, read and interpreted documents (Bowen, 2009). Document analysis enabled us provide data within contexts and helped secure supplementary and collaborative data for the study.

\subsection{Data Analysis}

Data analysis followed in the steps advanced by Moustakas (1994) and van Manen (2016). With transcribing interviews, participants were sent a copy to approve that what was captured. We read and re-read the scripts to have a fair understanding of the content (Shosha, 2012). The second step allowed us to develop a list of significant statements or what has been referred to as horizonalization of data (Goulding, 2005; Creswell, 2013). The third step saw us formulate meanings for every extracted significant statement. Textual description is a rich description with verbatim quotations from participants. The fourth step involved clustering formulated meanings into categories or themes. Clustered themes were incorporated to formulate a significant theme. In formulating themes, we were guided by the principle that themes are internally convergent and externally divergent. This meant that the meaning formulated from one theme applies to one cluster and this meaning was distinguished from the meaning of other clusters (Shosha, 2012). Clustering themes gave a structural understanding of the study and structural descriptions included the answers to the 'how' questions. Memoing and the sketch notes were our first line of thematic exploration as we embarked on data analysis. The fifth step was authenticating the data explicated using the member checking technique. The sixth step was the synthesis of the textual and structural descriptions. The sixth step helped us form a composite description of the phenomena and it informed the final report (Creswell, 2013). We therefore synthesized answers to 'what' and 'how' questions in developing apt understanding of the participant's experiences.

We used pseudonyms to protect the identity of the participants. In protecting the identity of participants, it was not possible for one to associate the views attributed to a pseudonym to a known individual. In addition to concealing the identity of the participants, pseudonyms were necessary in anonymizing our study as we captured individual and shared expectations that terror victims had of government communication. The data explicated from interviews was presented using discrete vignettes (Hughes \& Huby, 2002).

\section{FINDINGS}

The relationship between the government and citizens creates expectations on both parties. Some of these expectations are communicative in nature and such are the expectations that this study sought to examine. In the context of a terror attack, victims are desirous of communication from the government. At the center of managing citizen expectations are government communicators. Broom and Sha (2013) argue that government communicators are a critical link between the citizens and the government. It is the duty of government officials to communicate with citizens about what the government is doing while at the same time, taking feedback from the citizens to the government. During an attack, citizens have critical questions that need to be answered. They expect the government to respond to some of their concerns as government communicates. For instance, one participant David Omwami posed: why should we suffer as victims of a political process that does not involve us? Rael Wanjau framed her question as why would attackers target innocent students instead of facing the government?

To answer to the many questions posed at the time of a terror attack, government communicators are expected to respond to the different needs that create differentiated publics. Government communicators have a huge responsibility including informing citizens of the activities of the government (Theaker, 2016; Sanders and Canel, 2015); ensuring that citizens cooperate on 
government-initiated programs; facilitating media relations; and building partnerships between the government and the citizens (Broom \& Sha, 2013). This means that government communicators function as enablers in meeting the needs of various audiences. Drucker (2012) argues that communication is perceptional in that communication depends on both the source and receiver. Whatever the receiver does with the message received, that is what completes the communication process. Government messages were received depending with the expectations that victims had of government communication. Citing Plato's Phaedo, Drucker advises sources to any communication to speak or write in the language of the recipient. If a carpenter targets fellow carpenters, then this carpenter must use metaphors of a carpenter to reach out to fellow carpenters. It would be an expectation that the government would communicate in the metaphors so familiar to the victims of terror. Evidently, the second observation by Drucker that communication is exceptional helps create the expectations that terror victims had. Exceptional communication helps us estimate the responses or actions of sources or audiences. We thus create expectations of what we want to hear and see. The study returned findings showing a variety of expectations discussed in the sub-sections below.

\subsection{Personalized Government Communication}

Victims of terror expected the government to communicate in a personalized manner. Participants estimated the murderous effects of the attack as a matter that required personalized intervention and involvement of the government. Participants expected the government to communicate in their language and relate to their situation. That language demanded involvement and interpersonal relations. With a university population of about 800 students, one would see a similar number of families yearning for a clear involvement of the government in the issues the families were facing.

Rael Wanjau argued that government communication should have been structured to help government officials interact with terror victims. Rael called out the government over its announcement shortly after the attack that all was well - urging victims to pick up pieces and move on. Rael read mischief in this statement insisting that had the government been involved in victims' lives, such a statement would not have been communicated. In her words, Rael Wanjau affirmed that the "attack doesn't affect me, but the side effects do." Typically, Rael anticipated that the government would have walked with the victims to understand their pain points. Another participant Samson Lenawe tore into the president's address arguing that it did not carry the feelings, pains and concerns of the victims. To him, the speech was so generalized - focusing on the security situation in the country and seemed for the general public. While there was nothing wrong in communicating with the general public, but Samson wanted the message to target the victims as only a handful of Kenyans were affected by the attack on the Garissa University College.

Personalized communication also meant government presence. Terror victims expected that the government would be in their place and space. The study established the need to see government officials at the hospitals, mortuaries, educational pursuits, funerals - all spheres that characterized victims' lives at the time. Participants argued that government presence would have hastened closure. Invariably, the lack of government presence delayed closure. Morris Wekesa observed that the government had "never took the initiative to know if there was anyone else in the family it could reach out in the family and that is why the government has never concerned itself with us." David Mutiso captured the expectation of personalized communication when he argued:

I wanted the government to show its concern about the incident. I expected it to come first from the president then from all government officials. Instead, I noted that there was no concern for the survivors and to those who died. Similarly, when students were transferred to Moi University, we had hoped that government representatives would come in to support us. This did not happen.... It was not different at the military camp in Garissa. We had hoped to meet with the president, the cabinet secretary or a representative of the government, but no one addressed us. All that the government did was to send the NYS buses to ferry us to Nairobi.

Since the president had communicated that the entire country would be mourning with the families (Uhuru, 2015), participants expected government to be part of this process. Instead, the government adopted an incommunicado style. The government seemed to confuse relaying of information for communication Drucker (2012). As soon as victims started facing the vicissitudes of life, government went quiet. David Omwami argued: 
The government gave the burial support and never bothered to see what the future portended for the families. It was demoralizing that families had sacrificed their all only for their children to die in this tragedy. In such circumstances, it is only rational that the government would be there for the parents. It was heartbreaking to see the government fail to be involved, but it was saddening that government never fulfilled its promises.

\subsection{Structure that Supports Continuous Communication}

Participants expected structures in government that would ensure continuous communication. Morris Wekesa observed that the government had better systems compared to citizens. Government systems had the capacity to capture citizen data and use this data to reach citizens whenever need arises. Contrary to this expectation, Morris noted that government "never took the initiative to know if there was anyone else in the family it could reach out to and that is why I argue that the government has never concerned itself with us." Morris Wekesa was so surprised that instead of the government reaching out to him, government communicated and transacted with a family friend or a 'stranger' as Morris put it.

Participants had hoped that the national government administration officials (NGAO) would offer a better mechanism for the government to communicate and operate. It turned out that NGAO did not meet this expectation. Almost all participants mentioned their interaction with NGAO. Rachael explained how the local chief ensured that they safely walked to the military camp after they escaped from the attackers' snare. On his part, Morris Wekesa indicated that government had good channels running from the president to the local chief. He thought of NGAO as a popular government machinery that had previously worked efficiently. To Amos, NGAO provided an apt communication channel to the citizenry. He told us:

When the county commissioner receives information, he relays the same to his colleagues all the way to the local chief. A chief has a smaller administrative unit and has a fair understanding of the people living in this area. In case of death, God forbid, and such information must be relayed to the family, the government can access basic information from the national identity card and reach out to the relevant chief. The chief will get the information across to the family explaining to them what transpired. It would be wrong for the family to access such information from the social media.

David Omwami best represented participants expectations when he argued that government messages during the attack needed to percolate to the citizens without hinderance. Contrary to participant's expectations about NGAO that depicted the unit as a handmaiden for government communication and operations, experiences with the officials revealed an ineffective structure that stifled continuous communication. For instance, Morris Wekesa told us of NGAO:

The area chief is my neighbor. I had always considered myself lucky in that I would be the first to receive government messages once they are channeled to the administrator. My expectations were frustrated as it turned out that even the chief did not have the information I required. Since the attack, I noted the possibility that the government had ceased using the administrators to reach the citizens. How would the government abandon a channel of communication that served it with dedication?

Morris found it difficult to interrogate the intentions of the government. His only hope was that the local chief would have a better flow of what was happening. He was shocked that the local chief was uneasy on seeing top county administrators attend the interment of his daughter. The chief seemed clueless about the government procedure in paying respect to the departed and mistook the attendance of the country administrators for kinship with the deceased. for relationship. This put to question the efficiency of communication system of the government and whether government messages get to the right audience.

Rachael Mwangi wondered why NGAO did not perform as was expected. During the interment of her friend, Rachael noted that a local chief attended the service as part of his duty. When the chief rose to speak, he had no sympathies for the family. Instead, he updated mourners on the general security in the area and what the government was planning to do in the area. The chief never considered that his audience comprised of mourners. Rachael wondered why the official did not relay the right message for the moment. Rachael's observation suggests that there was a pose on the communication regarding 
the attack. At that point, NGAO seemed to be a government structure that did not support continuous communication.

The argument that government did not support continuous communication in government was further exacerbated by the failure to give victims updated messages. Participants looked forward to government communication prior to, during and after the attack only for communication to wane. Angela Mutinda noted that despite the communication challenges in the initial stages of the attack, she nonetheless expected government to continue updating victims of the attack on what was happening. She affirmed that she had not "received any communication from the government on how it conducted and concluded investigations on the attack." As for Angela, Morris Wekesa told me that he had never received any communication on the government investigations.

The anticipation that government communication needs to be continuous is supported in literature. Fairbanks, Plowman and Rawlins (2007) aver that government communicators need to constantly update citizens on what the government is doing. On their part, Sanders and Canel (2015) argue the place of constant government communication on the account that citizens need information to guide their decisions. In relaying information, government ought to give as much details so that the process engages the audiences and incorporates feedback (Drucker, 2012).

\subsection{Agility in Communication}

Whereas Grunig and Hunt (1984) theorized a stiff unidirectional governmental communication structure focused on looking at any favorably opportunities to paint the government in good light. Far from this sluggish communicative attitude, literature indicates a change in government communication with structures and process to accompany such alacrity (Canel \& Sanders, 2013). Participants in the study expected an agile government, one that should have utilized all available communication channels. Participants sought different channels expecting that the government would have used such avenues to communicate what was happening. In other words, victims of terror expected the government to communicate with them using the channels that victims preferred.

Instrumental to this finding was the need to have government communication to percolate to the citizen. Participants yearned to see a government that would have utilized the National Government Administration Officers (NGAO) who are spread all over the country to communicate and simplify government messages. Participant Morris Wekesa understood the surest way to communicate to the victims would have been through government officers. For Morris, the government had "good communication channels from the president all the way down to the clan elders" which enables the locals to interact with their local administrators and receive communication from government. He also pointed out that government officials are trained on communication protocols and would know how to approach all matters. Similarly, David Omwami preferred the use of government offices as on channel of reaching victims of terror. In using government officials, the officials immediately become spokespersons for the government.

Amos Kwena wished that the government would reign in on bloggers who spread fake news. Other participants made use of social media in seeking messages from the government. Terror victims expected the government to be tech-savvy and channel their communication as such. Joseph Luseli pointed to the possibility of a multifaceted approach that the government could have used. Joseph continually updated himself on the happenings by visiting social media networking sites. Joseph said he saw "messages on Facebook and on twitter such as \#Garissa University attack and \#we stand with you Garissa victims. These social media sites acted as social spheres where the victims congregated and as such, they expected the government to use the same forum to communicate.

All participants had phone and expected that phones would have been a channel for government messaging. Phone would have been an avenue for bulk messaging information that victims would have juxtaposed with their internet connectivity to the many information access points like government websites and social media sites. Most participants used the phone to communicate to their relatives and find out what was happening. Participants expected that the government would have used the same avenue to reach the victims of terror. John Mwangi paints a scenario of how he verified news about the attack through a politicians' phone. He had earlier been called by a relative to be informed of the attack. Later, the hospital informed him of his daughter's admission at Kenyatta National Hospital. 
The use of phones suggested that one needed a phone to secure the mass messaging options. This meant that availability of phones was a necessarily condition for government to use this option. Yet there was another supporting condition. Samson Lenawe explained how on the fateful day, someone called him to alert him about the attack, but his phone went off. Later in the interview, Samson told us he managed to escape with his phone, but he could not call anyone because the sim card got lost. The functional condition of the phone was equally important for such phones to be an avenue of communication. To this end then, while availability of a mobile phone remains a necessary condition for communication, the functionality of the phone becomes the sufficient condition. With these two conditions met, mobile phones would be handy for the government to relay crucial government messages on terrorism.

Some participants hoped that government would use radio to communicate. Samson Lenawe opined that "radio is highly accessible to most people." Radio was the alternative to social media especially for populations in the rural area. Morris Wekesa talked of rural populations depending on radio, television and newspapers. He preferred radio as it offered regular updates. Accessibility of radio would make flow of information easy as a "neighbor would hear something" and relay it to the rest of the community.

\subsection{Transparent and Prompt Communication}

Participants in the study also expected government communication to be open, prompt and specific. It would follow that the need to satiate specific details was high. When we asked him what he expected of government communication, Amos' response was that government communication ought to be "prompt, the more you wait the more the speculation. Communication is exact, it is prompt and it is specific." Angela Mutinda expected government communication on terror to be done "as soon as possible because government needed to rescue people with minimum casualties." Like Amos, Angela saw speculation as a detractor of efficient communication. Fast, accurate and truthful communication keeps speculation at bay. Prompt communication calms the anxiety among victims. Participants expected properly planned and executed government communication. In this context, David Omwami expected the government to "set communication timelines" to help manage audience expectations.

In addition to promptness, there was an expectation among participants that government communication needed to be detailed. Participants revealed the quest among terror victims to secure correct information. Terror victims wished to hear and read specific details. Specificity on government communication would ensure that information such as the time of attack, number of attackers, number of hostages, numbers rescued, numbers in hospital and number of those reported dead. David Mutiso captured the quest for correct details when he averred:

I wanted to know the actual number of those killed. Whereas the government reported that 147 lives had been lost, my simple calculation led me to doubt this number. When I compared the university population and the number of hostages rescued from the attack, I was persuaded that more than 147 people died as a result of the attack. I thus needed to hear the truth from the government. It does not hurt speaking the truth.

Asked what he would do differently if he were to advised government on communication, David saw truthfulness as a cardinal quality in government communication. On her part, Rael Wanjau expected an accountability framework that government institutions would use to communicate in an open manner. Open communication is supported by truthful conversations. Rael, as though considering the politics of numbers in communicating terror (Schmid, 2013), expected the government to openly carry out a list of the survivors so that families that could not see their kin on the list would "start preparing yourselves psychologically" should news about death come in. In other words, government ought to give details even where the government is uncomfortable. For Rael, government lacked depth in what it was saying. Angela Mutinda believed that the numbers given by the government did not reflect the accurate position. Accuracy on numbers was one of the things that victims expected. Once again, the trust in the machinery of government to crunch was expected. Government was expected to communicate about numbers that were well thought out and numbers that could be defended.

The expectation of promptness, specificity and transparency in government communication is completed by simplicity. Simplicity would have ensured that government messages are easily received and understood by both the urban and rural audiences. With victims of terror anticipating government communication to make informed decisions, the simplicity would ensure everyone got 
the message straight. Morris Wekesa's desire was that government "communication would be simplified." On his part, Joseph Luseli observed that government communication "should give us a clear picture and communicate effectively on what is happening on the ground." In communication, simplicity is a mark of quality.

\subsection{Well-Coordinated Messaging}

Government is a well-structured organization with functions specified in the various units. The government is thus expected to have its act right. It is perhaps this perception that led to the expectation that government communication presupposes good coordination and vice versa. In seeking such an understanding, participants painted a relationship between what the government said and what it acted upon. Participants envisaged government as an organization that did what it said and said what it did. Communication management is tied to the coordination or operations of government.

Anything that the government commits to undertake creates a communicative expectation. Participants talked about the expectations that action would be taken on what government commits to do. It is in this context that Angela Mutinda argued that "if government is going to make promises let it not be for the sake of saying but follow them with action and fulfil them. We were so anxious and the least that the government would do was to follow their sentiments with actions."

At the time of an attack, citizens are so cautious and may panic and think that there are enemies everywhere. Amos Kwena expected government to follow through its communication with action. Amos opined that the while the government did well in supporting the victims of terror, the gesture had coordination hiccups. On his part, David Omwami spoke of the need coordinate county and central government messaging and actions during a disaster. He spoke of how a message in the media costed him and other students the help they were to receive from county government. The governor had indicated that he would support them only to see a message indicating a similar support from central government. In the end, David and his colleagues ended up losing both pledges.

Angela Mutinda's account of coordination during the rescue of students depicted a government that was poorly coordinated. Angela expected to see a more coordinated government where security agencies communicate, share intelligence and intervene at the appropriate time. She could not understand how four attackers held the entire government waiting for 14 hours. Angela failed to see how poorly coordinated attackers though well armored managed to temporarily trounce the might associated with the Kenya security forces. In her opinion, had the elite Recce squad flown to Garissa that morning, very few students would have died. Another participant David Mutiso wondered whether the government had learnt from the previous attacks as he expected to see better coordination and communication during the attack on the university. David's sentiments spoke not only about to a history of ineffective government communication but also hoped that the goofs of yesteryears would be improved on in subsequent attacks.

One mark of a coordinated communicative government is accessibility. Participants wished for a government that would answer their questions. Morris Wekesa seemed to anchor the accessibility argument on the fact that those with information were hard to trace. He argued that what president says is law and his office is almost inaccessible to follow through on some of the pledges he made. Morris even narrated how difficult it would be to access government offices without evidence of what the officials had said. Morris wondered how many people kept the newspapers that quoted the president's speech and whether such evidence would grant someone access to the government offices. On his part, David Mutiso argued that victims "expected to meet with the president, the cabinet secretary or a representative of the government as we rejoined the university. We saw none." This showed that it was a challenge to access government officials

\subsection{Speak in One Voice}

Government is compartmentalized into ministries, departments and agencies (MDAs) with distinct but complementary communication units. From this mental picture, participants expected the government to speak in one voice. Participants expected a clear message from the president to his foot soldiers. Speaking in one voice meant that the communicators in government were aligned to their duties.

Anyone who spoke for the government needed to be in sync with what was happening in government. Participants expected the government spokespersons to mirror what the government had said or done. In making his assessment of what he expected of government communicators, Amos Kwena argued 
that government communication should be done "by the right person not just anyone giving information it should be very specific as to who will communicate. The communicators need to be aligned with what the government has resolved to communicate about." Angela Mutinda did not expect persons speaking on behalf of the government to be overly defensive or emotive when handling sensitive matters such as a terror attack. Her views are not far from Samson Lenawe's thoughts. For Samson, the government spokespersons should neither be abusive nor demean citizens as they work on behalf of the electorate.

Beneath the call for one voice, was the assumption that government is organized from the president down. When the president gives directives, or government takes a given position, participants expected the other government officials to take cue and follow suit. This confirmed the expectancy among participants that government would be well coordinated. Participant stories cited incidents where their expectation was not met. For some participants, what they expected to see public hospitals was not what they met. John Mwangi was given security to escort him and the daughter for a second medical opinion, as though he was a defaulter, yet the government had agreed to take care of the bills. Samson Lenawe was stopped by the police from accessing hospital when he sought safety and first aid having escaped the wrath of the attackers. Morris Wekesa narrated how a chief wondered how his poor family would marshal support from government. David Omwami and Samson Lenawe gave an account of how they received a donation meant for the students, but a public official made it impossible to secure the amount. These incidents spoke of government officials who were not attuned to the president's directive.

\subsection{Communicate Power and Authority}

In communicating about terror, participants expected government to communicate its and power. Government wields power and participants expected this to be part of government communication on terror. Participants expected that the government would communicate on investigations, arrests, warning to terrorists. For instance, Samson wished that government would interrogate the attackers, secure relevant information to deter future attacks. For Amos Kwena, the government has its "own ways of doing things" and these things should show that the government is in charge. For Amos, the way the government responds to an attack sends a clear message both to the victims and to the entire world. He held that a "halfhearted communication shows that the government is weak." Amos expected that government communication would be geared towards those who needed assistance. Participants expected a government that would send messages that endear the people to the government. Participants expected government to communicate on its legitimacy as a government elected by the people. Samson Lenawe agreed with the president "s declaration that the government would pursue the enemy at all costs.

\section{DisCUSSIONS}

In yearning for personalized communication, this study established that government needed to filter the needs, interests and concerns of the victims and use this postulation to formulate messages. Fairbanks, Plowman and Rawlins (2007) observe that to create an environment of transparency, government communication should reflect citizen needs interests and concerns. Based on needs, interest and concerns, government communicators can segment audiences and strive to meet the audience's communicative expectations. Had government segmented its audiences, the quest for personalized communication would have been aptly met (Moss, 2011). There is need for the government to be relentless in its communication to reach audience needs. Personalized communication means that government communication is a process and not an "isolated incident" (Smith, 1992:49). Terror victims expect the government to continuously keep them updated on the attack. It was an expectancy among victims that government communication should have continued as a circle - without stops. Some of the things that victims needed to hear included arrest of the perpetrators, interrogation, prosecution and conviction of the attackers. Government communication on terror is therefore not an end of the process but a mark of continuous communication. Government could have used agility to create communities of the victims and satiate their communication needs. McNeal, Hale \& Dotterweich (2008) position internet as one such avenue where government can inspire trust, quality and contact. While this may hold for urbanized populations, there is need for creativity that re-imagines the possible so that the rural folk are equally engaged. In the Kenyan 
context, terror victims preferred physical (and not virtual) involvement especially in times of death. The other downside with virtual engagements is that they thrive on channeling information as opposed to communication.

Agility in communication implored upon government communicators to utilize the different channels of communication. For starters, government officials are both spokespersons but also channels of communication. Kenya hoped to restructure the provincial administration within five years of the promulgation of the constitution (GoK 2010). Victims of terror saw the reformed provincial administration (now National government administration officers -NGAO) as a handy and vibrant communication tool in the hands of government. Interestingly, agility meant that government should seek all channels to communicate with audiences. Terror victims expect that the government would reach them through the victims preferred channels. The finding showed acceptability of social media, radio, online media, television and use of phones as exhibited within a context of mass messaging. Social media was associated with participation and openness (Hermida, 2012). Phones are accessible as channels for relevant information and avenues for interaction (Katz, 2008). There was less mention of the print version of newspapers. This finding seems to suggest that there was low readership of newspapers. The readership of newspapers have been waning with studies theorizing reasons for this behavior. Some of the reasons adduced include the popularity of radio, newspaper price, and emergence of digital version of the print newspaper (Oriare, Okello-Orlale \& Ugangu, 2010; Nyabuga \& Booker, 2013).

Discussions on the expectation of transparency and promptness is contemporaneous to discussions on ethical issues within government communication. Ethical issues such as libel, truth, sensationalism, hyperbolism (Grunig \& Hunt 1984); source credibility, respect for the audience, equity and social responsibility; and espionage (Bowen 2007) need to be considered. As a body corporate, the government needs to achieve what it set out to do by communicating to different audiences in a coherent, credible and ethical manner (Owakah \& Aswani, 2011). The study revealed the yearning of terror victims for a government that communicates truthfully. Truthfulness is associated with transparency or openness in government (Fairbanks, Plowman and Rawlins, 2007). Gaber (2007) ties the loose ends on communication within a democratic system arguing that an ideal situation is one where citizens are fully informed of the happenings in the government. Dewey (1927) argues that a good state is that which the public is organized and well informed by the government. Dewey maintained that there would be no public without full publicity. In his words, Dewey noted that "whatever obstructs and restricts publicity, limits and distorts public opinion and checks and distorts thinking on social affairs" (Dewey, 1927:167). Dewey's thought on democracy have semblance in how government communication is contemplated in the Kenya constitution. The constitution contemplates freedom of expression, freedom of the media and the access to information for all citizens. An open communication policy would have created an informed citizenry and that would have reinforced victims trust in government (Fairbanks, Plowman and Rawlins, 2007).

At the time of an attack, the public are a morally worried lot. Panic engrosses the country crystalizing fear that there could be enemies all around (Roth \& Muzzatti, 2004). How well a government is coordinated would communicate peace to the surviving citizens. Governments need to communicate their grip on security and assure citizens of their safety. Government communication should seek to inform, persuade, dissuade or makes pledges. Pfetsch \& Esser (2012) argue that government communication is contextualized in a political culture and public debate. This means that the governments are bound to make promises that need to be fulfilled. When promises are fulfilled, communication is connected to action.

The expectation that government would speak in one voice is not entirely new. Lattimore et al (2013) argue that a government that speaks in one voice has its communicators focused on telling the truth; proving communication with action; listening to the customer (audience); managing for tomorrow (generate goodwill); conducting public relations as if the whole company depends on it; and remaining calm, patient and good humored. Similarly, Steiner (1978) and Theaker (2016) ran an argument about neutrality in what civil servants do as they communicate to citizens. It is the position of the authors that citizens ought to see apolitical communicators. Gaber (2007) agrees with Steiner and Theaker arguing that government communicators should not spin and instead be neutral purveyors of information. 
Government communication involves communicating about power and how government distributes resources (Pfetsch \& Esser, 2012). Government should communicate authoritatively leaving no room as to who is in charge. Lattimore et al (2013) see democracy as a system hinged on the assumption that citizens cannot directly manage their own governmental affairs. Governments are regarded legitimate because they are voted into power by the electorate. The central role played by the citizens in a democracy obligates governments to frequently communicate to citizens. Lattimore et al argue that "citizens needed to be fully informed about issues and problems confronting them and actions taken by the government" (2013:318).

\section{CONCLUSION}

This paper explored answers to the research question seeking to establish what expectations terror victims had of government communication. Participants revealed varied communication needs needs that were linked to participants' expectations of government communication. Five expectations were themed out: personalized communication; agility in communication; transparency and promptness; well-coordinated messaging; and speaking in one voice. Argenti (2013) and Cornelissen (2014) posit that the basis of audience segmentation is audience needs, concerns and interests. Such communicators need to know that government communication is citizens' driven and need to be people centered (Gregory, 2012). Good government communication espouses the ideals of the system of governance. Democracy makes communicative demands on any government and this study shows that sections of the population drew from democratic ideals to make expectations of an open and equitable society. A well-coordinated government speaks of how well the government communicates. Young (2007) argues that communication is but a dimension of the things that government does. Government operations and coordination speaks of how government communicates. It is the finding of this study that coordination is linked to communication. Government operations is the clearest evidence of how government communicates.

\section{REFERENCES}

[1] Argenti, P. A. (2013). Strategic Corporate Communications. (6 ${ }^{\text {th }}$ ed.). McGraw-Hill Irwin.

[2] Bowen, S. A. (2007). Ethics and public relations. Institute for Public Relations.

[3] Boyd, C. O. (2001). Phenomenology the method. Nursing Research: A Qualitative Perspective, 3, 93-122.

[4] Broom, G. M., \& Sha, B. Y. (2013). Cutlip and Center's effective public relations ( $11^{\text {th }}$ ed.). Pearson

[5] Canel, M. J., \& Sanders, K. (2012). Government Communication: An emerging field in political communication research. In H. Semetko \& M. Scammell (Eds.). The Sage Handbook of Political Communication (pp 85-96). Sage.

[6] Colaizzi, P. (1978). Psychological Research as a Phenomenologist Views it. In: Valle, R. S. \& King, M. (1978). Existential Phenomenological Alternatives for Psychology. Open University Press.

[7] Cornelissen, J. (2014). Corporate Communications: A guide to theory and practice. (4th ed.). Sage.

[8] Creswell, J. W. (2009). Research Design, Qualitative, Quantitative, and Mixed Method Approaches. (3 ${ }^{\text {rd }}$ ed.). Sage.

[9] Creswell, J. W. (2013). Qualitative inquiry and research design: Choosing among five approaches. ( ${ }^{\text {rd }}$ ed.). Sage.

[10] Crotty, M. (2015). The Foundations of Social Research: Meaning and Perspectives in the Research Process. Sage Publications.

[11] De Gagne, J. C., \& Walters, K. J. (2010). The Lived Experience of Online Educators: Hermeneutic Phenomenology. Journal of Online Learning and Teaching, 6(2), 357-366.

[12] Dewey, J. (1927/1985). The Public and its Problems. Ohio University Press.

[13] Drucker, P. (2012). Management challenges for the 21st century. Routledge.

[14] Dukes, S. (1984). Phenomenological Methodology in the Human Sciences. Journal of Religion and Health, 23, 197-203. doi: 10.1007/BF00990785

[15] Fairbanks, J., Plowman, K.D., \& Rawlins, B. L. (2007). Transparency in government communication. Journal of Public Affairs. 7 (1), 23-37.

[16] Gaber, I. (2007). Too much of a good thing: the 'problem' of political communications in a mass media democracy. Journal of Public Affairs: An International Journal, 7(3), 219-234.

[17] Gadamer, H. G. (2013). Truth and method (J. Weinsheimer \& DG Marshall, trans.). Bloomsbury.

[18] Gentles, S. J., Charles, C., Ploeg, J., \& McKibbon, K. A. (2015). Sampling in Qualitative Research: Insights from an Overview of the Methods Literature. The Qualitative Report, 20(11), 1772-1789. 
[19] Gill, M. J. (2014). The Possibilities of Phenomenology for Organizational Research. Organizational Research Methods, 17(2), 118-137. doi: 10.1177/1094428113518348

[20] GOK, (2010). Kenya Constitution. Government printer.

[21] Gregory, A. (2012). UK Government communications: Full circle in the 21st century? Public Relations Review, 38(3), 367-375.

[22] Grunig, J. E., \& Hunt, T. T. (1984). Managing public relations. Holt, Rinehart and Winston.

[23] Goulding, C. (2005). Grounded theory, ethnography and phenomenology: A comparative analysis of three qualitative strategies for marketing research. European journal of Marketing, 39(3/4), 294-308.

[24] Grunig, J. E., \& Hunt, T. (1984). Managing Public Relations. Holt, Rinehart and Winston.

[25] Hermida, A. (2012). Tweets and truth: Journalism as a discipline of collaborative verification. Journalism Practice, 6(5-6), 659-668. doi.org/10.1080/17512786.2012.667269

[26] Hughes, R., \& Huby, M. (2002). The application of vignettes in social and nursing research. Journal of advanced nursing, 37(4), 382-386.

[27] Lattimore, D. L., Baskin, O. W., Heiman, S. T., Toth, E. L. (2013). Public relations: The practice and the profession. (4 ${ }^{\text {th }}$ ed.). McGrath.

[28] Letschert, R., Staiger, I., \& Pemberton, A. (Eds.). (2009). Assisting victims of terrorism: towards a European standard of justice. Springer Science \& Business Media.

[29] Lincoln, Y. S., \& Guba, E. G. (1985). Establishing trustworthiness. Naturalistic inquiry, 289, 331.

[30] Locke, J. (2014). Second treatise of government: An essay concerning the true original, extent and end of civil government. John Wiley \& Sons.

[31] McLeod, J. M., \& Chaffee, S. H. (1973). Interpersonal Approaches to Communication Research. American behavioral scientist, 16(4), 469-499.

[32] McLeod, J. (2011). Qualitative Research in Counselling and Psychotherapy. Sage.

[33] McNeal, R., Hale, K., \& Dotterweich, L. (2008). Citizen-government interaction and the Internet: Expectations and accomplishments in contact, quality, and trust. Journal of Information Technology \& Politics, 5(2), 213-229. https://doi.org/10.1080/19331680802298298

[34] Miles, M. B., Huberman, A. M. (1994). Qualitative data analysis: An Expanded Sourcebook. (2 ${ }^{\text {nd }}$ Ed.). Sage Publications.

[35] Moss, D. (2011). A managerial perspective of public relations: Locating the function and analyzing the environmental and organizational context. Public relations: a managerial perspective. Sage pp. 23-56.

[36] Moustakas, C. (1994). Phenomenological research methods. Sage publications.

[37] Nyabuga, G., \& Booker, N. (2013). Kenya, Country Report.

[38] Oriare, P., Okello-Orlale, R., \& Ugangu, N. (2010). The Media We Want: The Kenya Media Vulnerabilities Study: Nairobi. Friedrich Ebert Stiflung.

[39] Owakah, F. E., \& Aswani, D. R. (2011). The Ethics of Deontology in Corporate Communication. Thought and Practice, 3(1), 115-129.

[40] Parse, R. R. (1990). Parse's research methodology with an illustration of the lived experience of hope. Nursing Science Quarterly 3, 9-17. doi: 10.1177/089431849000300106

[41] Pfetsch, B., \& Esser, F. (2012). Comparing political communication. In Frank Esser \& Thomas Hanitzsch (Eds.). The Handbook of Comparative Communication Research (pp. 25- 47). Routledge.

[42] Rapin, A. (2011). What is Terrorism? Behavioral Sciences of Terrorism and Political Aggression, 3(3), $161-175$.

[43] Rothe, D., \& Muzzatti, S. L. (2004). Enemies everywhere: Terrorism, moral panic, and US civil society. Critical Criminology, 12(3), 327-350.

[44] Sanders, K., \& Canel, M. J. (2013). Government communication in 15 countries: Themes and challenges. In Sanders, K., \& Canel, M.J. (Eds.). Government Communication: Cases and Challenges (pp. 277-312). Bloomsbury.

[45] Schmid, A. P. (2013). Introduction. In Alex P. Schmid (Ed.). The Routledge Handbook of Terrorism Research (pp.1-37). Routledge.

[46] Shosha, G. A. (2012). Employment of Colaizzi's strategy in descriptive phenomenology: A reflection of a researcher. European Scientific Journal, ESJ, 8(27).

[47] Smith, D. K. (1992). Creating understanding: A handbook for Christian communication across cultural landscapes. Harper Collins.

[48] Smith, F., \& Flowers, P. Larkin. (2009). Interpretative phenomenological analysis: Theory, Method and Research. Sage Publication Ltd. 
[49] START (2016). Annex of Statistical Information. Country Reports on Terrorism 2015

[50] Steiner, R. (1978). Communication between government and citizen: Open or closed book? Southern Review of Public Administration, March, 542-561.

[51] Strauss, A., \& Corbin, J. (1998). Basics of qualitative research: Procedures and techniques for developing grounded theory. Sage

[52] Tavallaei, M., \& Talib, M. A. (2010). A general perspective on role of theory in qualitative research. Journal of International Social Research, 3(11), 570-577.

[53] Theaker, A. (Ed.). (2016). The public relations handbook. Routledge.

[54] Tench, R., \& Yeomans (2014). Exploring public relations. ( $3^{\text {rd }}$ Ed.). Pearson

[55] Van Manen, M. (2016). Researching Lived Experience: Human Science for an Action Sensitive Pedagogy. $2^{\text {nd }}$ ed. Routledge

[56] Van Ruler, B. (2015). Agile public relations planning: The reflective communication scrum. Public Relations Review, 41(2), 187-194. doi.org/10.1016/j.pubrev.2014.11.008

[57] Young, S. (Ed). (2007). Government Communication in Australia. Cambridge University Press.

Citation: Daniel Robert Aswani, et.al. "Exploring Terror Victims' Expectations of Government Communication". International Journal of Media, Journalism and Mass Communications (IJMJMC), vol 6, no. 4, 2020, pp. 07-19 doi: http://dx.doi.org/10.20431/2454-9479.0604002.

Copyright: (C) 2020 Authors. This is an open-access article distributed under the terms of the Creative Commons Attribution License, which permits unrestricted use, distribution, and reproduction in any medium, provided the original author and source are credited. 